\title{
CHROME BIOSORPTION AND CHEMICAL OXYGEN DEMAND REDUCTION FROM TANNERY WASTEWATER BY AEROBIC ACTIVATED SLUDGE
}

\author{
(Received: 9. 5. 2013)
}

\author{
By \\ R. S. Ahmed, G. M. Khalaf Allah , R. I. Refae, M. A. Ali and *M. H. Belal \\ Department of Microbiology and * Economic Entomology and Pesticides Department, \\ Faculty of Agriculture, Cairo University, Egypt.
}

\begin{abstract}
The leather industry is considered a polluting industry as it generates effluents which are characterized by high amounts of organic and inorganic load. One of the most important elements in the inorganic fraction is chrome. In this investigation, the capability of aerobic activated sludge to biosorp chrome was evaluated in a synthetic chrome solution and in tannery effluent. The wastewater contained a high levels of chrome (3014 mg/l) and COD (10306 mg/l). The estimated COD:N:P ratio was as high as 2015:30:1. In the synthetic chrome experiment, three concentrations of chrome were studied i.e. $100,500,1000 \mathrm{mg}$ chrome/l, where and chrome removal percentages reached 10.6, 9.3 and 11.9 , respectively. While in the tannery effluent, the removal percentage was very high; the chrome removal reached $99.98 \%$ after 6 days in undiluted and water diluted (1:2) effluent. The chemical oxygen demand (COD) was monitored during the tannery effluent treatment, where a $72.5 \%$ reduction at the sixth day was achieved.
\end{abstract}

Key words: activated sludge, chrome biosorption, COD reduction, tannery effluent.

\section{INTRODUCTION}

Chromium is found extensively in tanning industry effluent. When wastewater effluent, containing chromium, is discharged into the environment, it poses a serious problem to the quality of such an environment, therefore, removal of chromium from waste water is obligatory in order to avoid water pollution through removal of chromium before wastewater discharge. Legislation by different governments, demands that the concentration of $\mathrm{Cr}$ in discharges should be less than $0.5 \mathrm{mg} / \mathrm{l}$ (Water quality standards hand book $2^{\text {nd }}$ edition, 1993).

The current methods being employed, such as chemical precipitation, are not able to reduce the chrome concentration to the desired levels. Using various microorganisms as biosorbents for chromium removal, offers a potential alternative to existing methods for its recovery from industrial wastewater (Onyancha et al., 2008).

The discharge of effluents containing $\mathrm{Cr}$ (VI) and $\mathrm{Cr}$ (III) contains concentrations ranging from tenths to hundreds of $\mathrm{mg} / \mathrm{l}$. Hexavalent chromium is considered the most toxic form of chromium, whereas trivalent chromium is much less toxic. Because of these differences in its toxicity, the discharge of $\mathrm{Cr}$ (VI) into surface water is regulated below $0.05 \mathrm{mg} / \mathrm{l}$ by the U.S. EPA, while total $\mathrm{Cr}$ including $\mathrm{Cr}$ (III) and its other forms is regulated below $2 \mathrm{mg} / \mathrm{l}$ (Park et al., 2004).

The tannery, commonly use basic $\mathrm{Cr}$ (III) sulphate $\left[\mathrm{Cr}\left(\mathrm{H}_{2} \mathrm{O}\right)_{5}(\mathrm{OH}) \mathrm{SO}_{4}\right]$ in the tanning process (Sharma and Adholeya, 2011).

The first report on using bacteria in chrome reduction came out in the late of 1970's. Number of bacterial species have been isolated and shown to be capable of reducing $\mathrm{Cr}$ (VI). These species belong to Pseudomonas, Escherichia, Bacillus, Enterobacter and Sulphate-reducing bacteria (SRB) including Desulfovibrio, Desulfomicrobium and Desulphotomaculum. (Park et al., 2004).

Also, the activated sludge can be used as a detoxification agent to reduce $\mathrm{Cr}$ (VI) to $\mathrm{Cr}$ (III) and to adsorb $\mathrm{Cr}$ (III) on the suspended solids (Stasinakis et al., 2004).

The treatment and safe disposal of hazardous organic waste material in an environmentally acceptable manner and at a reasonable cost is a topic of great universal importance. Usually treatment of organic pollutants in wastewater is performed by applying two steps, firstly a chemical treatment, which targets the most nonbiodegradable fractions of wastewater; followed by a biological treatment (Mantzavinos and Psillakis, 2004).

Biomass synthesis, oxidation, denitrification 
and accumulation are elementary processes that take place in activated sludge during organic compounds COD removal (Dobrzynska et al., 2004).

The aim of this study was to monitor the chrome biosorption and chemical oxygen demand reduction from tannery wastewater using aerobic activated sludge.

\subsection{Materials}

\section{MATERIALS AND METHODS}

\subsubsection{Activated sludge}

Aerobic activated sludge was obtained from Zenien station for sewage water treatment, Giza, Egypt. It was aerated at $200 \mathrm{rpm}$ for $24 \mathrm{~h}$ after freshly obtained teo oxidize the organic matter that might be present.

\subsubsection{Heavy metal}

In a synthetic chrome batch system, $\mathrm{K}_{2} \mathrm{Cr}_{2} \mathrm{O}_{7}$ was used in three $\mathrm{Cr}^{+}$concentrations i.e., 100, 500 and $1000 \mathrm{mg} / \mathrm{l}$. Three replicates for each concentration were set up for $500 \mathrm{ml}$ Erlenmeyer flasks.

\subsubsection{Instruments}

An atomic absorption spectrophotometer (Thermo Electron Corporation) was used to measure heavy metal concentration, a cooling centrifuge (3K30) was used at $4800 \mathrm{rpm}$ for 20 min to separate the cells, a water bath adjusted at $75^{\circ} \mathrm{C} / 18 \mathrm{~h}$ for digesting cells, a rotary shaker (SI100) $100 \mathrm{rpm}$, thermo reactor (CR 3200) for the COD reaction $\left(150^{\circ} \mathrm{C}\right.$ for $\left.2 \mathrm{~h}\right)$ and a visible spectrophotometer (JEN WAY 6300) for COD determination at $600 \mathrm{~nm}$.

\subsubsection{Wastewater samples}

Tannery effluent wastewater was obtained from the tannery house in the region of Ein ElSera, Cairo, Egypt. At the chrome tanning stage of the leather tanning process, chemicals such as chrome sulfate were added to the pretreated leather.

All glassware used for the experimental purposes were washed with $0.1 \mathrm{M} \mathrm{HCl}$ before and after each experiment and subsequently rinsed with distilled water (Hussien et al., 2004).

\subsection{Methods}

2.2.1. Biosorption of chrome from synthetic chromium solution by aerobic activated sludge

The added activated sludge wt/v was $4.93 \mathrm{~g} / \mathrm{l}$. Three concentrations $(100,500$ and $1000 \mathrm{mg} / \mathrm{l})$ with three replicates of each concentration was placed in $500 \mathrm{ml}$ of distilled water plus $\mathrm{K}_{2} \mathrm{Cr}_{2} \mathrm{O}_{7}$ with activated sludge cells in Erlenmeyer flasks of $1000 \mathrm{ml}$ and shaked on a rotatory shaker at 150 rpm for up to 61 minutes. Periodical samples (20 $\mathrm{ml})$ were taken every $15 \mathrm{~min}$. and centrifuged at $4800 \mathrm{rpm}$ for $20 \mathrm{~min}$. The pellet was digested in 3 $\mathrm{ml}$ nitric acid $(60 \%)$ in a water bath at $75^{\circ} \mathrm{C}$ for $18 \mathrm{~h}$. The supernatant was acidified by adding one milliliter of nitric acid to ensure availability of the chromium ions for detection by the atomic absorption spectrophotometer. The chromium concentration in both pellet and supernatant was measured using the atomic absorption spectrophotometer. If the sample was diluted the corresponding multiplication was made.

\subsubsection{Tannery effluent treatment}

Experiments were performed using $500 \mathrm{ml}$ shaking flasks containing $250 \mathrm{ml}$ of the tannery effluent and shaked on a rotary shaker for up to 16 days. Two hundred and fifty of the tannery effluent was placed in $500 \mathrm{ml}$ flasks for each of the following treatments: undiluted control $(\mathrm{pH}$ adjusted to 6.0 by $\mathrm{NaOH} 0.1 \mathrm{~N})$, water diluted control (1:2) (without $\mathrm{pH}$ modification) and water diluted control (1:2) (pH adjusted to 6 by $\mathrm{NaOH}$ $0.1 \mathrm{~N}$ ). $10 \%$ inoculum of activated sludge was added to undiluted tannery effluent ( $\mathrm{pH}$ adjusted to 7 bt $0.1 \mathrm{NaOH} 0.1 \mathrm{~N}$ ) and to diluted tannery effluent (1:2) (pH adjusted to 6 by $\mathrm{NaOH} 0.1 \mathrm{~N}$ ). Periodical samples $(20 \mathrm{ml})$ were withdrawn and centrifuged at $4800 \mathrm{rpm}$ for 20 minutes. The supernatant was acidified by adding one milliliter of nitric acid to ensure availability of chrome for detection by atomic spectrophotometer; chrome was analyzed using the atomic adsorption spectrophotometer after dilution to be in the range of the standard curve.

\subsubsection{COD determination}

The COD was performed according to APHA (1992). Two and half of the sample to be examined was added into the COD glass tube followed by $1.5 \mathrm{ml}$ of digestion solution and 3.5 $\mathrm{ml}$ of sulfuric reagent. Tubes were then covered with screw caps, mixed well and put in the COD reactor at $150{ }^{\circ} \mathrm{C}$ for $2 \mathrm{~h}$. Blank and standard solutions were treated with the same manner as well. After digestion, tubes (samples, blank and standard) were allowed to cool and inverted several times and the solids allowed to settle before measuring absorbance. Measurements of the color intensity were carried out by spectrophotometer at $600 \mathrm{~nm}$.

\subsubsection{Statistical analysis}

Data obtained was statistically analyzed by least significant difference according to Gomez and Gomez (1984), and L.S.D. values at the 0.01 level of significance were used for comparison between means. 


\section{RESULTS AND DISCUSSION}

The tannery effluent was characterized by a high level of COD reached to $10360 \mathrm{mg} / \mathrm{l}$. Considering the $\mathrm{N}$ and $\mathrm{P}$ contents and the COD:N:P ratio was estimated to 2015:30:1. While the chrome content exceeded $3000 \mathrm{mg} / \mathrm{l}$. but the number of microorganisms did not exceed $3.5 \mathrm{cfu} / \mathrm{ml}$.

\subsection{Batch biosorption by activated sludge}

Fig.(1). illustrates the $100 \mathrm{ppm}$ chrome batch using the activated sludge. Experiment conditions were as follows, temperature $28^{\circ} \mathrm{C}$, shaking speed $150 \mathrm{rpm}, \mathrm{pH} 6$ and cell weight $4.93 \mathrm{~g} / \mathrm{L}$. The supernatant behavior of the $100 \mathrm{ppm}$ chrome batch was totally random and the net reduction at the best points was in the range of $10 \%$. While, the pellet behavior was unlike what was shown in the supernatant in that there was an increase in chrome level at 16 minutes which was maintained till the end of the batch.

Fig.(2). illustrates the 500ppm chrome batch using the activated sludge. Experiment conditions were as follows, temperature $28^{\circ} \mathrm{C}$, shaking speed $150 \mathrm{rpm}, \mathrm{pH} 5.3$ and cell weight $4.93 \mathrm{~g} / \mathrm{L}$. Concerning supernatant of the $500 \mathrm{ppm}$ chrome batch, there was a decrease in chrome from the first minute and this decline was maintained till the end of the batch. This was going in parallel with the increase of the chrome content in the pellet at the same time (first minute) and the continuity of this increment till nearly the end of the batch.

Fig.(3). illustrates the $1000 \mathrm{ppm}$ chrome batch for the activated sludge. Experiment conditions were as follows, temperature $28^{\circ} \mathrm{C}$, shaking speed $150 \mathrm{rpm}, \mathrm{pH} 5.3$ and cell weight $4.93 \mathrm{~g} / \mathrm{l}$. Concerning the supernatant of the $1000 \mathrm{ppm}$ chrome batch, there is a slight decrease in the overall chrome content of the batch, while in the pellet the increase in chrome accumulated started from the first minute and maintained till the end of the batch.

The L.S.D. 0.01 values were 3.52 and 0.003 for the supernatant and pellet, respectively for the three batches illustrated in Figures1, 2, and 3.

The reason for inefficient chrome removal in the three batches might be due to two factors. The first one is that, the chrome used was $\mathrm{Cr}(\mathrm{VI})$ which is according to (Ksheminska et al. 2005) considered to be highly toxic as it can be easily transported into microbial cells by the sulphate transport system and cause immediate reduction reactions leading to formation of various intermediates which are harmful to cell organelles, proteins and nucleic acids. The second factor is the $\mathrm{pH}$. According to Lin and $\mathrm{Yu}$ (2012), the optimum $\mathrm{pH}$ for maximum chromium removal is $\mathrm{pH} 5$, where as the mean of $\mathrm{pH}$ replicates in the three batches recorded during this study were 6 , 5.3 and 5.3 for the 100, 500 and 1000 ppm chrome batches respectively. Those $\mathrm{pH}$ values are considered higher than the optimum, and therefore, the chromium removal efficiency decreased due to osmotic and hydrolyzing effect (Sepehr et al., 2005).

Unexpectedly, only a marginal decrease in chromium concentration from solution was observed over the incubation period. Obviously, the biosorption capacity of the microbial cells was low, since the adsorbed chromium on the cells was very low. This could be explained by the activity of the functional groups and metal chemistry in solution (Yao et al., 2009). They also found that, the biosorption capacity began to decrease when $\mathrm{pH}$ increased (>5.0).

\subsection{Tannery effluent treatment}

In the undiluted effluent, the chromium decreased in the solution significantly below 1 $\mathrm{mg} / \mathrm{l}$ after 6 days of incubation either without or after addition of activated sludge (Table, 1). The observed growth of natural microflora in the bottles without sludge reaching $>300 \mathrm{cfu} / \mathrm{ml} \mathrm{might}$ be responsible for chromium biosorption.

In diluted effluents, however, another trend was observed. There was no growth of the natural microflora until day six; consequently very low chromium reduction $(2.6 \%)$ was recovered. After addition of activated sludge, the chrome could be reduced significantly to a concentration below $0.1 \mathrm{mg} / \mathrm{l}$ representing a removal efficiency of more than $99 \%$.

The results indicated that this high removal percentage did not occur in the batch experiments. This may be due to interactions between activated sludge and tannery wastewater components. Sepehr et al. (2005) reported that tannery water contains carbohydrates and organic acids (formic acid) that act as a carbon source of bacteria It also contains enzymes such as (tripsin and protease) as well as proteins of hide that act as sources of nitrogen. A tannery wastewater contains phosphorous so it has the most important elements which are essential for the microbial cells activity.

The overgrowth that was observed through all experiments duration confirms the activity of activated sludge. Nies, (1999) stated that, in order to grow in a chromate containing media, a biological system would need to develop a detoxifying tool by either extracellular or intracellular accumulation. 


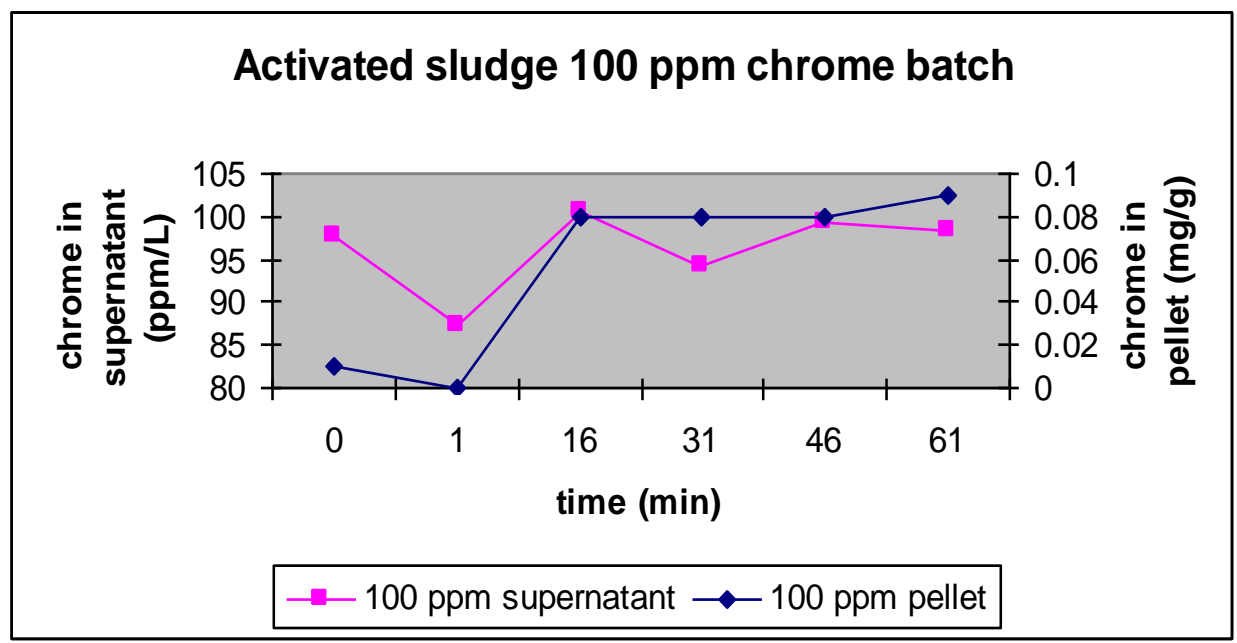

Fig. (1) : 100 ppm chrome batch of the activated sludge.

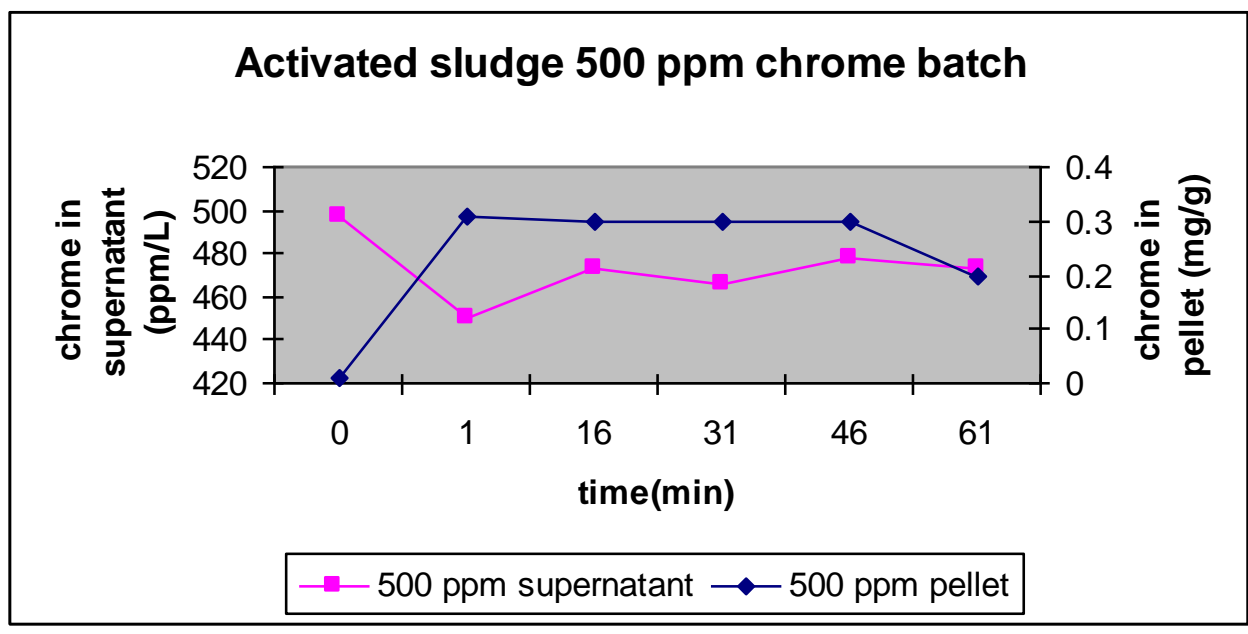

Fig. (2) : 500 ppm chrome batch of the activated sludge.

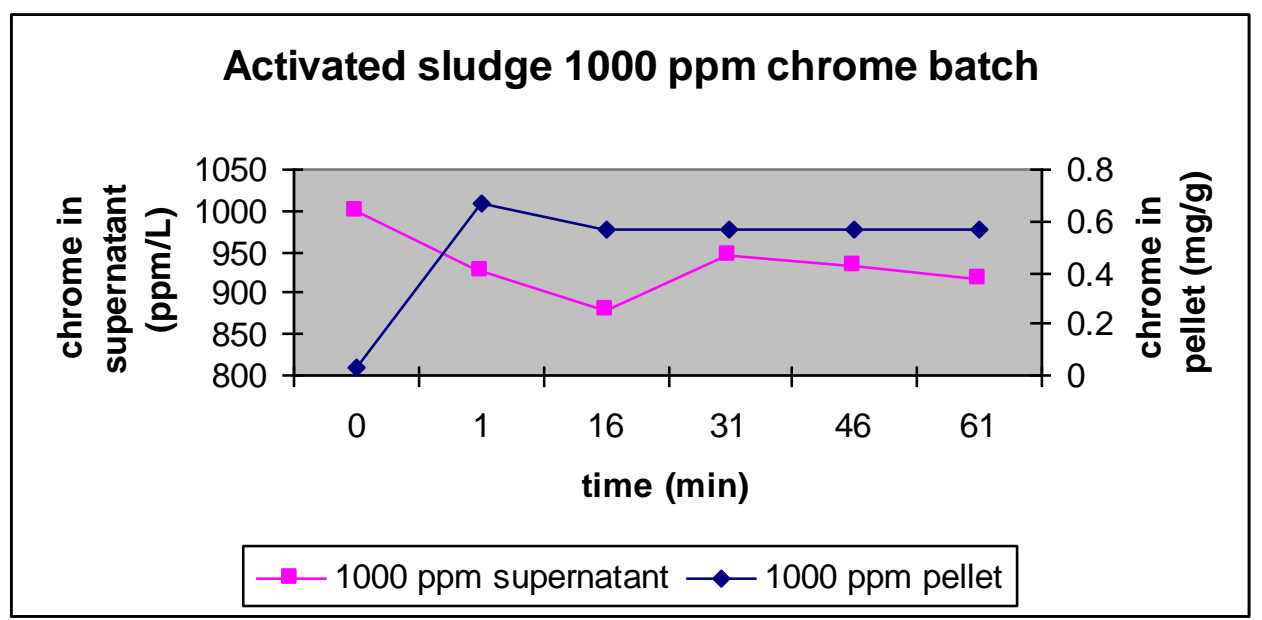

Fig. (3): 1000 ppm chrome batch of the activated sludge 
Table (1): Effect of control and activated sludge treatments of tannery effluent experiment.

\begin{tabular}{|c|c|c|c|c|c|c|c|c|}
\hline \multirow{2}{*}{ Treatment } & \multirow{2}{*}{ Parameters } & \multicolumn{7}{|c|}{ Time (days) } \\
\hline & & 0 day & 2 days & 4 days & 6 days & 10 days & 13 day & 16 day \\
\hline \multirow{4}{*}{$\begin{array}{l}\text { Control tannery } \\
\text { effluent } \\
\text { (undiluted) } \mathrm{pH}=6\end{array}$} & $\mathrm{COD}(\mathrm{ppm})$ & 10360 & 9060 & 9760 & 6860 & 6810 & 10610 & 8960 \\
\hline & $\mathrm{pH}$ & 6.08 & 5.9 & 6.1 & 6.7 & 5.5 & 6.5 & 7.4 \\
\hline & T.C.(cfu/ml) & 3.5 & 5 & 100 & $\begin{array}{c}\text { Over } \\
\text { growth }\end{array}$ & $\begin{array}{c}\text { Over } \\
\text { growth }\end{array}$ & $\begin{array}{c}\text { Over } \\
\text { growth }\end{array}$ & $\begin{array}{c}\text { Over } \\
\text { growth }\end{array}$ \\
\hline & $\mathrm{Cr}(\mathrm{ppm})$ & 3104 & --- & --- & 0.440 & -- & 0.195 & -- \\
\hline \multirow{4}{*}{$\begin{array}{l}\text { Control } \\
\text { Tannery effluent } \\
\text { (diluted1:2) } \\
\text { No pH } \\
\text { modification }\end{array}$} & $\mathrm{COD}(\mathrm{ppm})$ & 6010 & 5810 & 4060 & 3410 & 3960 & 8010 & 5710 \\
\hline & $\mathrm{pH}$ & 2.4 & 2.9 & 6 & 5.7 & 5.7 & 5.3 & 3 \\
\hline & $\mathrm{TC}(\mathrm{cfu} / \mathrm{ml})$ & $\begin{array}{l}\text { No } \\
\text { growth }\end{array}$ & $\begin{array}{l}\text { No } \\
\text { growth }\end{array}$ & $\begin{array}{l}\text { No } \\
\text { growth }\end{array}$ & $\begin{array}{l}\text { No } \\
\text { growth }\end{array}$ & 1 & 4 & 20 \\
\hline & $\mathrm{Cr}(\mathrm{ppm})$ & 1035 & --- & --- & 1007.90 & --- & 1149.70 & --- \\
\hline \multirow{4}{*}{$\begin{array}{l}\text { Tannery effluent } \\
\text { treated with } \\
\text { activated sludge } \\
\text { (undiluted) } \\
\text { pH modified to } 6\end{array}$} & $\mathrm{COD}(\mathrm{ppm})$ & 29513 & 9360 & 8710 & 4860 & 8910 & 8210 & 8260 \\
\hline & $\mathrm{pH}$ & 6.3 & 5.5 & 6.9 & 5.4 & 4.5 & 5.4 & 8 \\
\hline & $\mathrm{TC}(\mathrm{cfu} / \mathrm{ml})$ & $\begin{array}{l}\text { Over } \\
\text { growth }\end{array}$ & $\begin{array}{l}\text { Over } \\
\text { growth }\end{array}$ & $\begin{array}{l}\text { Over } \\
\text { growth }\end{array}$ & $\begin{array}{l}\text { Over } \\
\text { growth }\end{array}$ & $\begin{array}{l}\text { Over } \\
\text { growth }\end{array}$ & $\begin{array}{l}\text { Over } \\
\text { growth }\end{array}$ & $\begin{array}{l}\text { Over } \\
\text { growth }\end{array}$ \\
\hline & $\mathrm{Cr}(\mathrm{ppm})$ & 3104 & --- & --- & 0.310 & --- & 2.535 & --- \\
\hline \multirow{4}{*}{$\begin{array}{lr}\text { Wastewater } & (1: 2) \\
\text { treated } & \text { with } \\
\text { activated } & \text { sludge } \\
\text { (diluted) } & \\
\text { pH not modified }\end{array}$} & $\mathrm{COD}(\mathrm{ppm})$ & 9210 & 5360 & 5310 & 930 & 3210 & 3060 & 3310 \\
\hline & $\mathrm{pH}$ & 3.4 & 3 & 3.6 & 4.4 & 3.9 & 3.9 & 4 \\
\hline & $\mathrm{TC}(\mathrm{cfu} / \mathrm{ml})$ & $\begin{array}{l}\text { Over } \\
\text { growth }\end{array}$ & $\begin{array}{l}\text { Over } \\
\text { growth }\end{array}$ & $\begin{array}{l}\text { Over } \\
\text { growth }\end{array}$ & $\begin{array}{l}\text { Over } \\
\text { growth }\end{array}$ & $\begin{array}{l}\text { Over } \\
\text { growth }\end{array}$ & $\begin{array}{l}\text { Over } \\
\text { growth }\end{array}$ & $\begin{array}{l}\text { Over } \\
\text { growth }\end{array}$ \\
\hline & $\mathrm{Cr}(\mathrm{ppm})$ & 1035 & --- & --- & 0.060 & --- & 0.815 & --- \\
\hline L.S.D. 0.01 & \multicolumn{8}{|c|}{$\begin{array}{l}\text { L.S.D. for the COD values for the interaction between time and wastewater } \\
\text { treatments }=8.896 \\
\text { L.S.D. for the chrome values for the interaction between time and } \\
\text { concentration=5.250 }\end{array}$} \\
\hline
\end{tabular}

\subsection{Chemical oxygen demand (COD) reduction}

In undiluted effluent, results indicated that the COD significantly decreased in both treatments either with or without activated sludge (Table.1). However, the highest COD removal efficiency of 48.9\% (representing $775.5 \mathrm{mg}$ COD removed $\mathrm{l}^{-1} \mathrm{~d}^{-}$ ${ }^{1}$ ) was achieved in the presence of activated sludge after 6 days compared to only $33.8 \%$ (representing $583.3 \mathrm{mg}$ COD removed $\mathrm{L}^{-1} \mathrm{~d}^{-1}$ ) without sludge after the same time. Further incubation up to 16 day did not give any obvious decrease in COD concentration. The observed decrease in COD concentration in the absence of activated sludge might be due to the increase in natural microflora counts, which was doubled 30 fold by the $6^{\text {th }}$ day of incubation.

While in a diluted effluent, a similar trend of COD decrease was observed in both treatments, before and after addition of activated sludge. Although the initial $\mathrm{pH}$ value was within the acidic range the removal percentages of COD in both treatments were relatively as high as (43.3 and 64.1, respectively) than those observed in undiluted effluent (Table 1).

\section{REFERENCES}

APHA (1992). Standard methods for examination of water and wastewater $18^{\text {th }}$ edition. American Public Health Association, Washington,D.C.

Dobrzynska A., Wojnowska-Baryla I. and Bernat K. (2004). Carbon removal by activated sludge under fully aerobic conditions at different COD/N Ratio. Polish Journal of Environmental Studies, 13(1):33-40.

Gomez K.A. and Gomez A.A.(1984) Statistical Procedures for Agricultural Research. $2^{\text {nd }}$ Ed., Wiley \& Sons, New York, U.S.A.

Hussein H., Ibrahim S.F., Kandeel K. and Moawad H. (2004). Biosorption of heavy metals from wastewater using Pseudomonas sp. Environmental biotechnology, 7(1)

Ksheminska H., Fedorovych D., Babyak L., Yanovych D., Kaszycki P. and Holoczek H. (2005). Chromium(III) and(VI) tolerance and bioaccumulation in yeast: $\mathrm{A}$ survey of cellular chromium content in selected strains of representative genera. 
Process Biochemistry, 40:1565-1572.

Lin W. and Yu L. (2012). Biosorption behavior and mechanism of lead(II) from aqueous solution by aerobic granules (AG) and Bacterial alginate(BA). J. Ocean Univ. China, 11(4):495-500.

Mantzavinos D. and Psillakis E. (2004). Enhancement of biodegradability of industrial wastewaters by chemical oxidation pre-treatment. J. Chem. Technol. Biotechnol., 79:431-454.

Nies D.H.(1999). Microbial heavy metal resistance. Appl. Microbiol. Biotechnol., 51:730-750.

Onyancha D., Mavura W., Ngila J. C., Ongoma P. and Chacha J. (2008). Studies of chromium removal from tannery wastewaters by algae biosorbents, Spirogyra condensate and Rhizoclonium hieroglyphicum. Journal of Hazardous Materials, (158): 605-614.

Park D., Yun Y. and Park J. M. (2004). Use of fungal biomass for detoxification of hexavalent chromium: screening and kinetics. Process Biochemistry, 40: 2559-
2565.

Sepehr M. N., Nasseri S., Mazaheri Assadi M. and Yaghmaian K. (2005). Chromium bioremoval from tannery industries effluent by Aspergillus oryzae. Iran J. Environ. Sci. Eng., 2(4): 273-279.

Sharma S. and Adholeya A. (2011). Detoxification and accumulation of chromium from tannery effluent and spent chrome effluent by Paecilomyces lilacinus fungi. International Biodeterioration \& Biodegradation, 65: 309-317.

Stasinakis A., Thomaidis N.S., Mamais D. and Lekkas T.D. (2004). Investigation of $\mathrm{Cr}(\mathrm{VI})$ reduction in continuous-flow activated sludge systems. Chemosphere, 57: 1067-1077.

Water quality standards hand book, $2^{\text {nd }}$ ed. (1993). EPA-723-B- 93-002 and EPA-823-B94006.

Yao L., Ye Z. M.., Tong Lai P., and Ni J. (2009). Removal of $\mathrm{Cr}^{3+}$ from aqueous solution by biosorption with aerobic granules. Journal of Hazardous Materials, 165: 250-255.

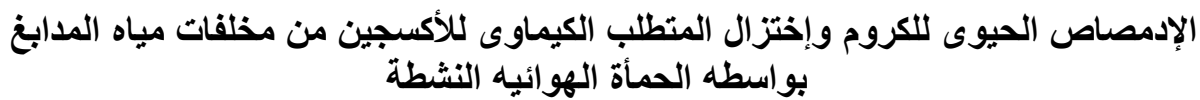

رشا سمير احمد - جلال محمود خلف الله - رفاعى ابراهيم رفاعى - محم عبد الطليم على - * محمد حلمى بلال

قسم الميكروبيولوجيا الزر اعيه _* قسم الحشرات الاقتصاديه و المبيداتـ كليه الزر اعه- جامعه القاهرهـ الجيزة

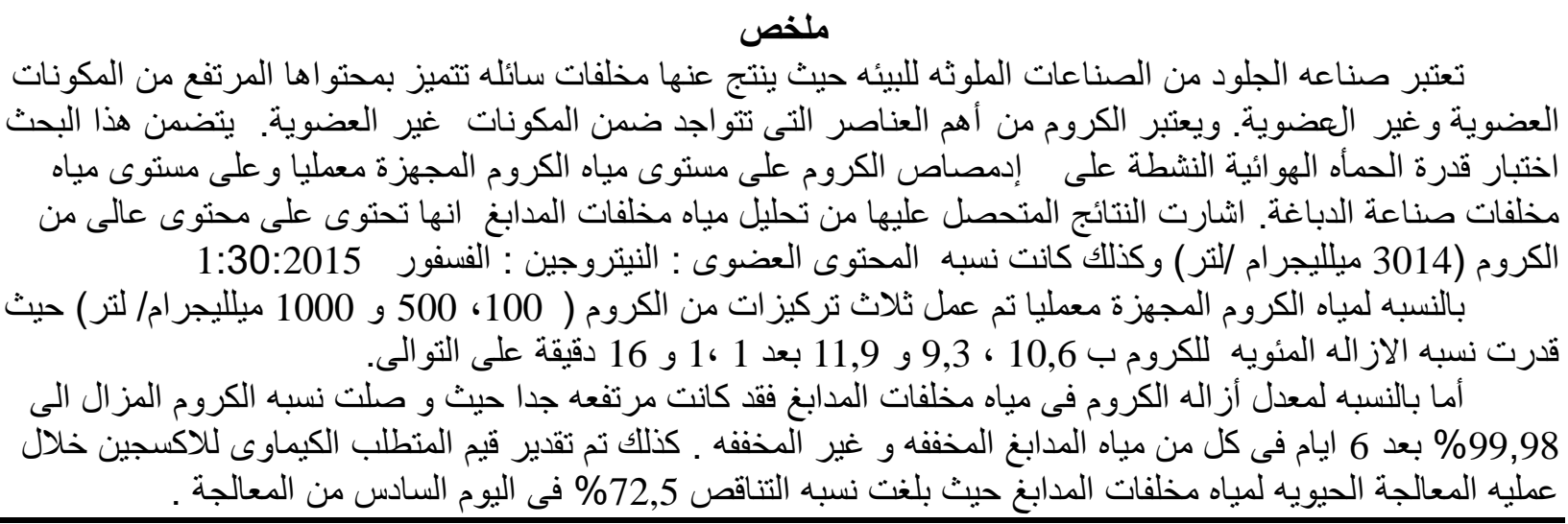

المجلة العلمية لكلية الزراعة - جامعة القاهرة ـ المجلد (64) العدد الثانى (ابريل 2013): 204- 209. 